\section{AB1172 ARE CIRCULATING BLOOD BIOMARKERS FOR INFLAMMATORY RHEUMATIC DISEASES GENDER- DEPENDENT? - SYSTEMATIC REVIEW BASED ON OMICS DATA}

Ana Filipa Fernandes ${ }^{1}$, Atlas Sardoo ${ }^{2}$, Fernando Pimentel dos Santos ${ }^{2}$, Ana Varela Coelho ${ }^{3} .{ }^{1}$ Universidade Trás-os-Montes e Alto Douro, Vila Real, Portugal; Vila Real, Portugal; ${ }^{2}$ NOVA University of Lisbon, CEDOC, NOVA Medical Schooll faculdade ciências médicas, Lisbon, Portugal; ${ }^{3}$ NOVA University of Lisbon, Instituto Tecnologia Química e Biológica, Oeiras, Portugal

Background: Inflammatory rheumatic diseases (IRDs) are thought to be multifactorial diseases. Female-male ratio in IRDs differs according to the disease ${ }^{1}$. In Rheumatoid Arthritis (RA) and Systemic Lupus Erythematosus (SLE) female prevalence is higher opposing to Ankylosing Spondylitis $(\mathrm{AS})^{2,3}$. Until recently, differences on gender-bias observed in predisposition to IRDs, and to their pathophysiologies have been understudied and neglected. Recent research using omics approaches shows that genderbias is outspread in a diversity of pathologies. The integration of omics results, spite the extremely complex crosstalk among the several biomolecules involved, places these methods at the lead of medical research, overcoming limitations and increasing the forecasts of targeted methodologies $^{4-6}$.

Objectives: The purpose of this systematic review is to aggregate existing omics results on biomarkers for RA, SLE and AS to raise awareness about whether gender can actually play a role on their profiles.

Methods: Two searches were conducted on PUBMED database (22nd November 2018) with a final output of 81268 articles. Both searches were sorted by best matches and for the second thousandth articles ranked no relevance was found for the aim of this review. The first 1000 articles were further analyzed based on the title, abstract and content. Three articles having relevant results were selected from the first thousand publications. Ten more were identified from the cross-references of both searches. The PICO ( $\mathrm{P}$, population; I, intervention; C, comparison; $\mathrm{O}$, outcome) concept was used to perform the analysis according to: Patients: adults (>18 years old) with RA, SLE or AS (SpA); Intervention: any -omic study; Comparison: gender information regarding results; Outcomes: identified genes, proteins or metabolites.

Results: Dectin-2, MCP-1 and DC-SIGN polymorphisms where proposed as possible accounts for gender-associated differences in susceptibility to $R^{7}$. Sex-differentiated and sex-interaction analyses of a GWA study revealed strong evidence of association in both sexes, highlighting links with RA only in one of the genders ${ }^{8}$. Several transcriptomic studies pointed to gender differences on biomarkers profiles for the three diseases. For instance, different expression levels of TNF $\alpha$, IL-6, IL-17, IL18, IFN $\alpha$ as well as $X$ or $Y$ chromosome-linked genes were found in SLE and/or $A S^{9-11}$. In AS, male patients with syndesmophytes showed higher levels of TNF $\alpha$ and men without syndesmophytes presented higher levels of VEGF, IL-6, TNF $\alpha$ and IL-18 both compared to femalesmatched $^{12}$. In RA patients, microRNAs 222, 532, 98, and 92a were found significantly down regulated in PBMC of female versus male ${ }^{13}$. Six genes displayed a gender-biased expression among male and female SLE patients ${ }^{14}$.

Conclusion: Blood biomarkers signatures for the IRDs analyzed in this study have been shown gender-biased. These will contribute for a better understanding of these diseases pathophysiology and probably to different gender approaches regarding diagnosis, monitoring and therapeutic approach.

\section{REFERENCES}

[1] Amur S, et al. (2012),38,J254;Nussinovith U, Shoenfeld Y(2012),11,6; van Vollenhoven $\operatorname{RF}(2009), 7,1$;

[2] Effler SW, et al. (2013),39,101;

[3] Russell C et al(2013),4,395;

[4] Song X, Lin Q(2017),37,1257;

[5] Cáliz R, et al. (2013),8,e72732;
[6] Zhuang JJ,Morris AP(2009),3,Suppl 7:S90;

[7] Gracey E et al(2016),68,679;

[8] Hui-Yuen $\mathrm{J}$ et al(2016),45,394;

[9] Wang XB et al(2017),18,184;

[10] Huang WN et al(2012),15,163;

[11] Khalifa Oet al(2016),17;

[12] Martin AR et al(2018),

Disclosure of Interests: Ana Filipa Fernandes: None declared, Atlas Sardoo: None declared, Fernando Pimentel dos Santos Grant/research support from: From Abbvie and Novartis, Speakers bureau: Abbvie, Novartis Pfizer, Biogen, Ana Varela Coelho: None declared DOI: 10.1136/annrheumdis-2019-eular.8161

\section{AB1173 ENDOCARDIAL LESIONS IN PATIENTS WITH RHEUMATIC DISEASES: CASE REVIEW}

Sergio Rodríguez Montero, Consuelo Ramos Giráldez, PLAZA NAHIA, Jose Luis Marenco. Valme Hospital, Rheumatology, Seville, Spain

Background: The infection of a native or prosthetic heart valve usually occurs in patients with structural valvular anomalies that predispose to turbulent flows. Manifestations such as arthralgia, arthritis or back pain appear in up to $40 \%$ of patients, which acts as a confounding factor when this infection occurs in patients with rheumatic diseases. On the other hand, in the latter patients, noninfectious endocarditis has been described, which adds even more complexity to the diagnosis.

Objectives: To describe the characteristics of endocardial lesions in patients with rheumatic diseases.

Methods: Patients attending clinics at the Department of Rheumatology were analyzed to determine how many of them required hospitalization for causes directly related to endocardial lesion, from January 2015 until December 2018. The following information was recorded: age, sex, type of rheumatic disease, duration of the disease, immunosuppressive treatment, characteristics of endocardial lesions, complications of endocardial lesions, and cardiovascular risk factors.

Results: All patients were identified from an electronic database. Results regarding to demographic and clinical data are as follows:

Conclusion: The spectrum of endocardial involvement in patients with rheumatic diseases is variable. In this case review, we found lesions of different origin: infectious, thrombotic and tumoral. The appearance of fever of unknown origin in patients with rheumatic diseases, requires ruling out an endocarditis, needing transesophageal echocardiography in case the transthoracic study, which is less sensitive, is negative. It is striking the case of patient 3 , a systemic sclerosis with calcinosis in limbs, whose endocardial wart, was studied histologically, revealing in its composition mainly calcium and fibrin. We have not found a bibliographic reference of calcium endocarditis in systemic sclerosis.

In conclusion, patients with rheumatic diseases can develop infectious endocarditis, but also thrombotic valvular vegetations, as well as myxo mas whose consequences, from their clinical debut, may pose life-threatening situations for the patient. The presence of fever, stroke or embolic events in these patients should put us on the track of an underlying endocardial involvement.

\section{REFERENCES}

[1] Am J Med (2007) 120, e1-e2

[2] World J Cardiol 2014 September 26; 6(9): 993-1005

[3] Rev Esp Enferm Metab Óseas 2002;11(2): 50-58

Disclosure of Interests: Sergio Rodríguez Montero: None declared, Consuelo Ramos Giráldez Speakers bureau: Sanofi, NAHIA PLAZA: None

\begin{tabular}{|c|c|c|c|c|c|c|c|c|c|}
\hline & Age & Sex & Rheumatic disease & Baseline Treatment & $\begin{array}{c}\text { Endocardial lesions } \\
\text { clinical debut }\end{array}$ & $\begin{array}{l}\text { Blood } \\
\text { culture }\end{array}$ & Endocardial lesions & Complications & Clinical evolution \\
\hline $\begin{array}{l}1^{\circ} \\
\text { case }\end{array}$ & 27 & Male & Dermatomyositis & $\begin{array}{l}\text { Methotrexate }+ \\
\text { glucocorticoids }\end{array}$ & $\begin{array}{l}\text { Digital ulcers + } \\
\text { Febrile syndrome }\end{array}$ & $\begin{array}{l}\text { Staph. } \\
\text { Aureus }\end{array}$ & Infectious endocarditis & $\begin{array}{l}\text { Mitral valve } \\
\text { perforation }\end{array}$ & $\begin{array}{c}\text { Resolution after cardiac } \\
\text { surgery }\end{array}$ \\
\hline $\begin{array}{l}2^{\circ} \\
\text { case }\end{array}$ & 64 & Male & Rachialgia & NSAIDS & Febrile syndrome & $\begin{array}{l}\text { Strept. } \\
\text { Gallolyticus }\end{array}$ & Infectious endocarditis & - & - \\
\hline $\begin{array}{l}3^{\circ} \\
\text { case }\end{array}$ & 53 & Female & Systemic Sclerosis & $\begin{array}{l}\text { Tocilizumab + } \\
\text { glucocorticoids }\end{array}$ & Febrile syndrome & - & $\begin{array}{c}\text { Nonbacterial thrombotic } \\
\text { endocarditis }\end{array}$ & $\begin{array}{c}\text { Acute ischaemia } \\
\text { right lower limb }\end{array}$ & Resolution after embolectomy \\
\hline $\begin{array}{l}4^{\circ} \\
\text { case }\end{array}$ & 13 & Female & $\begin{array}{c}\text { Autoinmune } \\
\text { hemolytic anemia }\end{array}$ & $\begin{array}{l}\text { Glucocorticoids, } \\
\text { splenectomy }\end{array}$ & Ischaemic stroke & - & Auricular myxoma & - & $\begin{array}{c}\text { Systemic lupus ANA and anti- } \\
\text { DNA + }\end{array}$ \\
\hline $\begin{array}{l}5^{\circ} \\
\text { case }\end{array}$ & 48 & Female & $\begin{array}{c}\text { Autoinmune } \\
\text { thrombocytopenia }\end{array}$ & Glucocorticoids & Iliac artery embolism & - & Auricular myxoma & - & $\begin{array}{l}\text { Immunologic síndrome } \\
\text { secondary to myxoma }\end{array}$ \\
\hline
\end{tabular}


declared, Jose Luis Marenco Speakers bureau: abbie, pfizer, novartis, janmsen

DOI: 10.1136/annrheumdis-2019-eular.6217

\section{AB1174 IS MONITORING SYNOVITIS IN THE HANDS BY ULTRASOUND ENOUGH TO ASSESS TREATMENT EFFECT IN PATIENTS WITH RA IN CLINICAL PRACTICE?}

Dolores Ramos-Bello ${ }^{1}$, Hilde Berner Hammer ${ }^{2}$, Mette Bjørndal Axelsen ${ }^{1}$, Mikkel Ǿstergaard ${ }^{1,3}$, Sin Ngai $\mathrm{Ng}^{4}$, Merete L. Hetland ${ }^{1,3}$, Susanne Juhl Pedersen ${ }^{1}$, Lene Terslev ${ }^{1} .{ }^{1}$ Center for Rheumatology and Spine Diseases, Rigshospitalet, Copenhagen, Denmark; ${ }^{2}$ Diakonhjemmet Hospital, Oslo, Norway, ${ }^{3}$ Department of Clinical Medicine, Faculty of Health Science, Copenhagen University, Copenhagen, Denmark; ${ }^{4}$ Queen Elizabeth Hospital, Medicine department, Hong Kong, China

Background: The use of ultrasound (US) as a tool for assessing disease activity in patients with rheumatoid arthritis (RA) has increased in recent years and its value is supported by studies showing that US provides more accurate assessment of joint inflammation than clinical examination at time of diagnosis and in clinical state of remission.

Various scoring systems have been proposed for monitoring of synovitis. Among these are the novel consensus-based Global OMERACT-EULAR Synovitis Score (GLOESS) was developed applying the highest score of grey-scale (GS) or Doppler as the final score for the joint.

Different joint sets have been proposed for optimal and feasible evaluation of patients with inflammatory arthritis but currently there is no agreement on a specific reduced set of joints that should be evaluated by US to acquire the best information about clinical and subclinical activity when monitoring patients with RA.

Objectives: To evaluate if synovitis assessment of hands only is enough (testing GS, Doppler and GLOESS sum scores) for assessing changes during treatment in order to increase clinical feasibility of US in daily clinical practice.

Methods: US and clinical assessment for tender/swollen joint count (TJC/ SJC) were performed in 19 patients fulfilling ACR 1987 criteria for RA initiating treatment with TNF inhibitor (TNFi) (week 0), and after 6 and 16 weeks of follow up.

Forty-six joints were evaluated by US (sternoclavicular, acromioclavicular, glenohumeral, elbow, wrist, MCP1-5, PIP1-5, hip, knee, ankle and MTP 1-5 bilaterally) using a GE Logiq E9 machine with a linear array transducer. Joint inflammation was graded $0-3$ on GS and Colour Doppler (CD) and synovitis was defined as a GS score $\geq 1$ with or without Doppler score $\geq 1$. Doppler settings for slow flow was applied according to guidelines.

\begin{tabular}{|c|c|c|c|c|c|c|c|c|c|}
\hline & Baseline, & Median & lar & & Median & $10 \mathrm{P}$ & Week 16, tho & & \\
\hline & rho & & & $\begin{array}{l}\text { Weekb, } \\
\text { rho }\end{array}$ & & & & Median & $10 R$ \\
\hline GS 28-joint & 0.94 & 8 & 2-18 & 0.88 & 4 & $1.2-15.7$ & 0.95 & 6 & $1-16.5$ \\
\hline CD 28-joint & 0.94 & 2 & $0-6.5$ & 0.93 & 0 & 0.6 .5 & 0.95 & 0 & $0-4$ \\
\hline 28-GLOESS & 0.93 & 8 & $2-8$ & 0.87 & 4 & $1.2-18.5$ & 0.89 & 6 & $1-17.5$ \\
\hline GS hands & 0.90 & 5 & $1-10$ & 0.78 & 3 & $1-10.7$ & 0.87 & 5 & $0.5-9.5$ \\
\hline $\begin{array}{l}\text { CD hands } \\
\text { nagss }\end{array}$ & 0.92 & 1 & ${ }_{1-11}^{0-4}$ & 0.91 & 0 & 0.5 & 0.95 & 5 & $\begin{array}{r}0.3 .5 \\
0.05 .11\end{array}$ \\
\hline Hands GLOESS & 0.88 & $\frac{6}{3}$ & $1-11$ & 0.78 & 3 & $1-10.7$ & 0.81 & 5 & $0.50-11$ \\
\hline GS 9-joints & 0.51 & 3 & $0-10$ & 0.54 & 0 & $0-4$ & 0.30 & 3 & 0.3 \\
\hline CD 9-joints & 0.81 & 5 & 1-10.2 & 0.73 & 0 & $0-5$ & 0.83 & 5 & $0-9$ \\
\hline 9-GLOESS & 0.95 & 5 & 2-14 & 0.94 & 4 & $1.2-10.5$ & 0.86 & 3 & $0-9$ \\
\hline
\end{tabular}

Table

GS, CD and GLOESS sum scores were obtained for the total joint set and different joint subsets: hands as joint set (wrist, 1-5 MCP, 1-5 PIP bilaterally), 28 conventional joints evaluated for DAS and the 9-joint set suggested for the GLOESS (shoulder, elbow, wrist, MCP1 and 4, PIP2, MTP 3 and 5, knee). Data from the different joint sets were analyzed applying Spearman's correlation coefficient.

Results: Mean change in GS sum score between week 0 and 16 was of $2.58,1.35,1.47$ and 1.11 for 46 -joint set, hands, 28-joint set and 9joint set, respectively. Compared to the 46 joint set the GS and CD sums core had a high correlation coefficient $(>0.78)$ for 28 joint set and the hand as joint set for all time points - table 1. The 9 joint set GS sum score had low correlation when compared to the 46 joint set at baseline and during follow up - table 1. GLOESS for the hands performed equally well with a correlation coefficient $(\geq 0.70)$ for all joint sets at all time points - table 1. DAS28-CRP did not correlate with the total joint set or the different joint subsets.

Conclusion: The present study of patients with RA shows that the US examination of both hands only for assessing disease activity is highly correlated for with the 46-joint evaluation at all time points, both regarding GS and Doppler sum scores. Using hands as a reduced joint set US assessment of inflammation could be an option to increase the feasibility of US in routine clinical practice.

Disclosure of Interests: Dolores Ramos-Bello: None declared, Hilde Berner Hammer Grant/research support from: AbbVie, Pfizer and Roche, Paid instructor for: AbbVie, Pfizer, UCB, Novartis, Roche, Speakers bureau: AbbVie, Pfizer, UCB, Novartis, Roche, Mette Bjørndal Axelsen: None declared, Mikkel Ǿstergaard Grant/research support from: Abbvie, Celgene, Centocor, Merck, Novartis, Consultant for: Abbvie, BMS, Boehringer-Ingelheim, Celgene, Eli Lilly, Hospira, Janssen, Merck, Novartis, Novo, Orion, Pfizer, Regeneron, Roche, and UCB, Speakers bureau: Abbvie, BMS, Boehringer-Ingelheim, Celgene, Eli Lilly, Hospira, Janssen, Merck, Novartis, Novo, Orion, Pfizer, Regeneron, Roche, and UCB, Sin Ngai Ng: None declared, Merete L. Hetland Grant/research support from: BMS, MSD, AbbVie, Roche, Novartis, Biogen, Pfizer, Consultant for: Eli Lilly, Speakers bureau: Orion Pharma, Biogen, Pfizer, CellTrion, Merck, Samsung Bioepis, Susanne Juhl Pedersen: None declared, Lene Terslev Speakers bureau: Speakers fee from : Roche, Novartis, Pfizer, MSD, BMS, Celgene

DOI: 10.1136/annrheumdis-2019-eular.6842

\section{AB1175 2 FACET JOINTS INVOLVEMENT IN RHEUMATOID ARTHRITIS: A CROSS-SECTIONAL STUDY}

Tatiana Reitblat ${ }^{1}$, Lina Linov ${ }^{2}$, Fadi Badeer ${ }^{2}$, Azaria Simonovich ${ }^{2}$, Leonid Kalichman ${ }^{3} .{ }^{1}$ Barzilai MC, Rheumatology Unit, Ashkelon, Israel; ${ }^{2}$ Barzilai MC, Radiology, Ashkelon, Israel; ${ }^{3}$ Recanati School for Community Health Professions, Faculty of Health Sciences at Ben-Gurion University of the Negev, Department of Physical Therapy, Beer-Sheva, Israel

Background: Even it is accepted among rheumatologists that rheumatoid arthritis (RA) does not involve the facet joints (FJs) of the spine, the issue is still under debate. Studies that described a prevalence of the FJs in rheumatoid arthritis patients are scarce.

Objectives: To compare the prevalence of FJs changes between patients with RA and age and sex-matched peers.

Methods: We compared computed tomography (CT) scans of 34 patients with RA, who suffered from low back pain, and 70 age and sex-matched controls-people without RA, with low back pain.

The changes in FJs were evaluated according to the score proposed by Kalichman et al: joint space narrowing, marginal osteophytes, articular process hypertrophy, subchondral sclerosis, inter-joint vacuum phenomenon, and subchondral cysts. The characteristic joint changes of RA were also evaluated.

Disease activity characteristics, duration of RA, age, and gender were taken from patients' clinical charts.

Results: Prevalence of facet joints changes in patients with RA and group of age and sex-matched controls were not significantly different at any spinal level or in total L5-S1 score. Marginal erosions, that are characteristic feature of joint change in RA, were not found in any subject with RA in our sample. In subjects with RA, individuals with affected FJs and without affected FJs have no difference in any disease parameters and markers (Tables 1 and 2).

Conclusion: In our samples of CT scans we did not find a difference in facet joints changes between the subject with RA and control group. The occurrence of FJs changes among subjects with RA had no correlation with disease duration and activity. According to the findings, we may assume, that facet joints of the lumbar spine are not involved in the inflammatory process of RA, and patients' low back pain is not due to inflammation in this region of the spine.

Abstract AB1175 Table 1. Prevalence of FJ degenerative changes in patients with RA and age and sex-matched controls.

\begin{tabular}{lccc}
\hline Segment & RA patients & Controls & Comparison $\left(\chi^{2}\right.$-test) \\
\hline L1-L2 Left & $1(3.0 \%)$ & $1(1.8 \%)$ & $\chi^{2}=0.157$, d.f. $=1, p=0.692$ \\
L1-L2 Right & $0(0.0 \%)$ & $0(0.0 \%)$ & - \\
L2-L3 Left & $0(0.0 \%)$ & $1(1.7 \%)$ & $\chi^{2}=0.575$, d.f. $=1, p=0.448$ \\
L2-L3 Right & $1(3.0 \%)$ & $1(1.8 \%)$ & $\chi^{2}=0.157$, d.f. $=1, p=0.692$ \\
L3-L4 Left & $2(6.1 \%)$ & $2(3.4 \%)$ & $\chi^{2}=0.363$, d.f. $=1, p=0.547$ \\
L3-L4 Right & $1(3.0 \%)$ & $4(6.9 \%)$ & $\chi^{2}=0.605$, d.f. $=1, p=0.436$ \\
L4-L5 Left & $2(6.1 \%)$ & $2(3.4 \%)$ & $\chi^{2}=0.342, d . f .=1, p=0.559$ \\
L4-L5 Right & $4(12.1 \%)$ & $3(5.3 \%)$ & $\chi^{2}=1.370$, d.f. $=1, p=0.242$ \\
L5-S1 Left & $4(12.1 \%)$ & $5(8.9 \%)$ & $\chi^{2}=0.233, d . f .=1, p=0.629$ \\
L5-S1 Right & $0(0.0 \%)$ & $5(8.8 \%)$ & $\chi^{2}=3.065$, d.f. $=1, p=0.080$ \\
Total L1-S1 score & $9(27.3 \%)$ & $11(19.0 \%)$ & $\chi^{2}=0.846, d . f .=1, p=0.358$ \\
\hline
\end{tabular}

